\title{
Study of Audit Risk under the Fair Value Measurement Mode
}

\author{
Yong-chen $\mathrm{Li}^{1}$, Yuan-yuan Liu ${ }^{1}$, Zhi-yuan $\mathrm{Liu}^{2}$ \\ ${ }^{1}$ Department of Economic Management, North China Electric Power University \\ ${ }^{2}$ Auditing Department, North China Electric Power University
}

\begin{abstract}
Fair value measurement model is a difficult point of the academic research topic at home and abroad. The current research in China is still in the exploratory stage, so the audit under the fair value measurement model will have a lot of uncertainty. This paper is on the basis of interpretation of the fair value auditing theory, focuses on analyzing the impact of fair value measurement model of audit risk and its specific performance. At the same time, it will analyze the impact of deep level reason, accordingly put forward countermeasures and suggestions of reducing the risk of the fair value audit, in order to promote the continuous improvement of the fair value audit and development.
\end{abstract}

Index Terms - Fair Value, Fair Value Audit, Audit Risk

\section{Basic Theory of Fair Value Audit}

A. Determination of Fair Value Measurement Attribute and Amount

Fair value accounting is the basis of fair value audit under the guidance of fair value idea, the development and perfection of fair value accounting theory will help the certified public accountants improve the audit quality and efficiency in practice. There are still many disputes about fair value accounting at present, there is no more unified and mature viewpoint in many important issues, the uncertainty of accounting standards and their guidelines. In general, the measurement attribute of fair value is still in the initial exploration stage in our country, need to study and summarize the latest theoretical research results at home and abroad, improve the fair value accounting and audit theory and the improvement of the method.

\section{B. The Basic Implication of Fair Value Audit}

From the development of fair value audit, fair value audit is developed along with the development of fair value accounting. Because of the large use of fair value in measurement, it makes the auditor use fair value audit when audit the company's business. Fair value audit mainly is refers to the CPA audit of the financial statements in the process and in the implementation to obtain sufficient and appropriate audit evidence on the basis of the necessary audit procedures, to determine the specific assets, liabilities and equity of the project or transaction fair value recognition and measurement, including initial measurement and subsequent measurement and disclosure is in accordance with the provisions of the applicable accounting standards and the accounting system and draws the corresponding audit conclusion.

\section{Analysis of the Current Situation of Fair Value Measurement Model of the Impact of Audit Risk}

The current audit risk model of our country is as follows: the audit risk equal to the risk of major errors and the multiplication of inspection risk. The following will start from these two risks, the impact of the fair value of the measurement of the audit risk.

\section{A. The Risk of Major Errors}

Material misstatement risk refers to the financial statements before the audit exists the possibility of material misstatement, material misstatement risk and audit risk of related and exist independently in the audit of financial statements, the fair value accounting needs through its own development and perfect to deal with from fair value accounting system external environment risk, his paper focuses on the internal risk, internal risk can be further subdivided into the inherent risk and the risk of CPA behavior.

\section{B. Check Risk}

The risk of inspection is the fault of a certain recognition, the fault report alone or in conjunction with other errors is significant, but the CPA failed to find the possibility of the error. The main factors that affect the audit risk are three aspects, the attitude of the auditor, the ability of the job, and the working method.

In the attitude of the work, the auditor should observe the principle of independence, objectivity and impartiality, and the fair value measurement mode and other measurement mode are the same as this one.

In terms of ability to work and professional competence, fair value measurement, due to stand trial range and audit testing and is an inherent limitation of the scope of the audit, audit personnel on the evidence and the use of evidence, there a lot of uncertain factors, auditors need strengthen the sense of responsibility and professional care, with keen analytical ability and accurate professional judgment ability. But not every auditor can meet the above requirements. It is more prone to audit operation is not standardized, out of touch with the audit procedures, subjective assume, by work experience and other issues.

Because of the subjectivity of fair value measurement and the poor operability, if the choice of audit method is inappropriate, it will also affect the correctness of the audit conclusion.

\section{Audit Staff for Violating the Risk of Occupational Morality}

Due to the subjectivity of the fair value measurement model, estimation technology and strong features, coupled with the auditors in is audit unit to make the favorable pressure 
on audit report, if abide by professional ethics is not firm, may in the fair value measurement value is difficult to determine and subjectivity is large, luck, agreed by the audit unit's point of view and thus issue false audit report. Even if the auditors comply with the basic principles of professional ethics, auditors will also face greater efficiency pressures. Especially when audit a complex or for auditors is relatively unfamiliar, efficiency under the pressure, auditors more vulnerable to affected by audit unit, they give the estimate of the model. These audit actions violate the basic principle of professional ethics and then cause the audit failure.

\section{The Cause Analysis of the Impact of Fair Value Measurement Mode on Audit Risk}

\section{A. Fair Value Business Risk}

From the results of commodity trading, the value of the commodity is not stable, so there is no price stability. The same kind of commodity, often in different markets, often have different prices; even in the same time, the same market, the same goods for different customers, it may have different prices. The price of two kinds of commodity exchange can only be formed in the negotiation of buyers and sellers.. Regardless of the exchange, consciously or unconsciously, they negotiate basis are presented with each other the value of the goods in the minds of every price comparison, the sellers hope bid each other than white has identified the value of high, the more the better, the buyers hope bid each other than white has identified the value lower the more the better.

Value judgment is subjective, as audit judgment result value is subjective, with characteristics of uncertainty, not to this value judgment to deny the rationality of value judgment of history

\section{B. Difficulty of Fair Value Measurement}

Due to the constraints of fair value measurement, many factors have to rely on judgment and estimation, so fair value determination and fairness has also become a major challenges to the fair value measurement model. Fair value appraisal has the very strong subjective randomness. When an active market fair trade price does not exist, you need to turn to in present value, present value is the fair value measurement, but present value determined is really a said easy difficult thing. On the one hand because the market is not active, the lack of a fair price formation mechanism, for most of the assets and liabilities, it is difficult to find the market value.

On the other hand, the fair value to determine the main form -- the use of present value technique, due to different investors, between investors and management authorities expected return on investment rate cannot be completely unified, have large uncertainties in estimates of future cash flows, resulting in specific technical operation difficulty bigger, together with both the choice of discount rate or of the future cash flow estimates, are inseparable from the subjective judgment and uncertainty about the future events, so these subjective factors exist in increased the uncertainty of fair value will no doubt greatly increased the enterprise accounting personnel "capture" the difficulty of fair value.

Therefore, auditors can on accounting recognition and measurement of fair value and accounting methods selection of appropriate, compliance to make objective and impartial audit evaluation is particularly critical, if auditors lack corresponding to the fair value judgment and the ability to grasp will face the risk that find and determine the fair value of the "unfair".

\section{The Non-adaptation of the Professional Quality of Auditors}

China's current market economy is still in the stage of gradual improvement, the use of the inherent need to improve the fair value of the market economy has a considerable risk. Because the present market economy, to find, identify true fair value with considerable difficulty, auditors need to economic, technological and market environment highly comprehensive judgment and ability to grasp.

\section{The Lack of Audit Theory and Method}

Although the new enterprise accounting standards use fair value, but the new audit criteria did not mention the fair value of the deal. There is no special theoretical framework or guide for the implementation of fair value audit to provide scientific basis. In addition, the fair value audit has not yet formed a comparison standard, standard methods of audit, audit and certified public accountant (CPA) there is no uniform evaluation criteria and audit trail, this will inevitably increase the difficulty of the fair value audit.

Such as in the audit personnel selection method to test, the compound and an independent estimate of fair value recognition and measurement and audit results and Book results may exist error, although acceptable error is the problem of audit sampling technology, but in the fair value audit error acceptable degree will directly affect to confirm the reliability of fair value, but audit error in what range of is auditors or financial report users can accept and bear, new accounting and auditing standards did not be singled out, no gives a calculation can accept the error range of the method. Such auditors in the implementation of the fair value of the audit may because there is no uniform evaluation criteria and audit trail, and makes the normal implementation of the audit greatly reduced

\section{Countermeasure and suggestion}

\section{A. Improve the Comprehensive Market Environment}

Measurement target of fair value measurement model is an estimate of the market price of an asset or liability, the market environment is directly related to in fair value measurement observable input data fully and measurement results of the comparison, and ultimately affect the reliability of fair value and improvement of the different structures of the fair value hierarchy.

To the country, it is to use all kinds of means and methods to promote the development of market environment.. For example, the state should provide guarantee for the institution to develop reliability verification of fair value for the 
development of the policy. At the same time, the state should also continuously revised perfect "criminal law", "accounting law" and the fair value of the related laws, by a severe blow to break the law, increase the cost of illegal, to the implementation of fair value really create a good environment.

Speaking of the enterprise, improve the market environment first of all, we should constantly improve the corporate governance structure, because congenital defects existing in the corporate governance structure of our country has become the fair value of the use of a major cause of inadequate. Enterprises to realize the diversification of property rights, and to maintain the consistency of the use of fair value valuation method and policy, on a regular basis to regulators and the board will reflect the use of fair value and on an enterprise's financial position and profitability impact.

\section{B. Establish Fair Value Measurement Frame System}

In 2006, the financial accounting standards board (FASB) released the financial accounting standards (SFAS157), which presents the theoretical framework of guidance on fair value expounded in detail, the fair value of the objectives, scope, confirmation, measurement, disclosure and the entry into force of the period and the transition period, and the definition of fair value, the initial recognition, subsequent recognition and valuation technology, assets and liabilities and their application, the fair value hierarchy and the detailed specification, clear and comprehensive exposition of the fair value measurement.

In China's new accounting standards system, due to the related to the fair value measurement and disclosure requirements are distributed in different accounting standards, not the system and improve the, so in practical operation is likely to can not be effectively implemented. To this end, we hope to be able to draw on the FASB's experience, the establishment of including practitioners, professional committee, to develop specific guidelines for fair value measurement, the fair value of the identification, definition, disclosure and application norms, and complement and explanation about specific valuation techniques and reference information.

\section{Establish Third Party Guarantee}

At present, our assessment industry in addition to the threshold of the qualification examination, assessment division in the enterprise value assessment in addition to have included accounting, management, marketing, investment analysis, computer information systems and other related knowledge, but also should have some special skills, such as data analysis, professional experience, risk judgment ability and competence.. The certified public accountant can use the effective assessment results of the auditor to make more convincing judgment for the audit unit to make use of the change of measurement mode and to manipulate the profit..

The government should also strengthen of asset appraisal institutions supervision system construction, establishing the assessment working group, institutions to assess the quality of work assessment, establish the dynamic entry and exit mechanisms and follow-up tracking system and the responsibility investigation system. In order to make fair value measurement more reliable, it is necessary to establish fair value assessment system to standardize the assessment data sources, methods and results. Because of the objective existence of the market, all market participants expect information than that obtained from the expectations of individual enterprises information more objective and more easily, can better prepare market evaluation system. Therefore, to establish a strong information database, accumulation of industry data, not only can think auditors to the enterprise of fair value measurement parameters, and can provide auditors with the main indicators of the authoritative enterprise fair value assessment, so as to make the fair value audit according to the smooth implementation of the laws.

\section{Cultivate High Quality Auditing Talents}

In our country, the CPA is financial reports and other relevant information announced before the identification of people, the gatekeepers of is the company's financial reporting and audit, to a large extent, the level of information quality will be affected by the CPA's professional quality level. Therefore, in order to guarantee the fair value of the audit quality, improve the professional competence of the CPA is one of the effective ways. The professional competence of certified public accountant is the CPA, in order to be qualified for its audit, and must have the professional knowledge, professional judgment, professional morality and its value, etc.

\section{Conclusion}

In order to enhance the idea of honesty of CPA, maintenance good professional image, and in practice the process strictly follow the practice guidelines, can strengthen the professional ethics education and publicity of certified public accountants. At the same time, through strengthening professional training to make audit personnel in a timely manner to understand and complement the latest knowledge about fair value accounting and auditing, and become familiar with and master the fair value measurement model and the valuation methods, so that it can improve the auditor's professional judgment ability. In addition, the need to focus on the cultivation of audit personnel risk awareness and professional skepticism.

\section{References}

[1] FASB. Statement of Financial Accounting Standards No.157: Fair Value Measurements. www.fasb.org,2006-09-15

[2] IASB. International Financial Reporting Standards No.13:Fair Value Measurements. www.iasb.org,2011-05-12

[3] Edward E. Nusbaum. Top 10 Wish List for Audit Research: Current Issues in Auditing. American accounting association, 2007, (1):c3-c9

[4] IFAC. International Standards on Auditing No.545: Auditing fair value measurements and disclosures.www.ifac.org,2002-07-18

[5] Roger D. Martin, Jay S. Rich, T. Jeffrey Wilks. Auditing Fair Value Measurement: A Synthesis of Relevant Research. Accounting Horizons, 2006-9-15

[6] Alfred M. King. Fair Value for Financial Reporting. John Wiley and Sons Publications, 2006, 47-57 